Kajian Jurnalisme

Volume 05 Nomor 01 Tahun 2021

DOI: $10.24198 / j \mathrm{kj} . \mathrm{v} 5 \mathrm{i} 1.33458$

\title{
Peran Pers Sebagai Aktor Gerakan Digital Tagar \#SolidaritasUntukNTT di Twitter
}

\author{
Gema Nusantara Bakry dan Ika Merdekawati Kusmayadi \\ Fakultas Ilmu Komunikasi, Universitas Padjadjaran \\ gema@unpad.ac.id
}

\begin{abstract}
The flash flood caused by the Seroja Cyclone in NTT has attracted the attention and sympathy of the Indonesian people. One of the efforts made by the Indonesian people to mitigate the impacts received by the people of NTT is campaigning for the digital social movement \#SolidaritasUntukNTT on Twitter. These movements can raise awareness, and the effectiveness of message dissemination of digital social movement can be visualized by using the Social Network Analysis (SNA). This study aims to visualize the role of the press in distributing digital social movement messages with the hashtag \#SolidaritasUntukNTT. The research method used is SNA with graph theory on Twitter. The results of network analysis and visualization were carried out in the Gephi application with the Yifan Hu algorithm to determine the distribution of message patterns and the role of the press on the \#SolidaritasUntukNTT. This study describes a two-mode network type of interactions between individuals and organizations with a radial personal network communication pattern that features open networks and low cohesiveness with directed and asymmetrical relationships. The role of the press is measured through the centrality of the actors to determine the degree of centrality, closeness centrality, betweenness centrality, and eigenvector centrality. The results of the study showed that the actor@vice id has the highest centrality degree and eigenvector centrality compared to other actors.While@idntimes and@detikcom have higher closeness and betweenness centrality values than other media. SNA provides an understanding of the distribution of messages in social media to determine the effectiveness of messages distributed by several network actors, particularly the role of the press.
\end{abstract}

Keywords: actor centrality; networking; press; social movement; Twitter

\begin{abstract}
Abstrak
Peristiwa banjir bandang yang diakibatkan Siklon Seroja telah mengundang perhatian dan simpati masyarakat Indonesia. Berbagai upaya telah dilakukan untuk berkontribusi dalam upaya penanggulangan dampak yang diterima oleh masyarakat NTT. Salah satu upaya yang dilakukan oleh masyarakat adalah mengampanyekan gerakan sosial digital \#SolidaritasUntukNTT di Twitter. Gerakan sosial digital melalui pesanpesan tertentu dapat menggugah kesadaran bagi penggunanya. Untuk mengetahui efektivitas penyebaran pesan dalam gerakan sosial digital dapat divisualisasikan menggunakan metode Social Network Analysis (SNA). Penelitian ini bertujuan untuk memvisualisasikan peran pers dalam mendistribusikan pesan gerakan sosial digital dengan tagar \#SolidaritasUntukNTT. Metode penelitian yang digunakan adalah analisis jaringan sosial dengan teori graf di Twitter. Hasil analisis dan visualisasi jaringan dilakukan di aplikasi Gephi dengan algoritma Yifan Hu untuk melihat distribusi pola pesan dan peran pers pada tagar \#SolidaritasUntukNTT. Penelitian ini menggambarkan tipe jaringan two mode yang terdiri dari interaksi antara individu dan organisasi dengan pola komunikasi radial personal network yang memiliki ciri jaringan terbuka dan kohesivitas yang rendah dengan arah relasi directed dan asimetris. Analisis peran pers diukur melalui sentralitas aktor untuk mengetahui degree centrality, closeness centrality, betweenness centrality dan eigenvector centrality. Aktor @ vice id diketahui sebagai aktor yang memiliki degree dan eigenvector centrality tertinggi dibandingkan dengan aktor pers lainnya. Aktor@idntimes dan@detikcom memiliki nilai closeness
\end{abstract}

Korespondensi: Dr. Gema Nusantara Bakry, M.Si., Fakultas Ilmu Komunikasi Universitas Padjadjaran, J1. Raya Bandung Sumedang KM.21, Kec. Jatinangor, Kabupaten Sumedang, Jawa Barat, 45363 Email:gema@unpad.ac.id

Menyerahkan: Mei 2021, Diterima: Juli 2021, Terbit: Juli 2021

ISSN: 2549-0559 (cetak), ISSN: 2549-1946 (online), Website: http://jurnal.unpad.ac.id/kajian-jurnalisme 
dan betweenness centrality yang lebih tinggi dari media lainnya. Analisis jaringan sosial memberikan pemahaman terkait distribusi pesan dalam media sosial untuk mengetahui efektivitas pesan yang didistribusikan oleh beberapa aktor jaringan, khususnya peran pers dalam mengampanyekan gerakan sosial di media. Oleh karena itu, metode SNA dapat digunakan untuk penelitian jurnalisme data.

Kata kunci: gerakan sosial; pers; sentralitas aktor; tipe jaringan; Twitter

\section{PENDAHULUAN}

Peristiwa bencana alam yang terjadi di Nusa Tenggara Timur (NTT) telah menarik perhatian masyarakat Indonesia di berbagai penjuru Nusantara. Bencana alam banjir bandang ini telah menumbuhkan rasa kesadaran manusia untuk bergerak membantu sesamanya. Berbagai gerakan sosial masyarakat hadir untuk membantu mengurangi dampak penderitaan masyarakat di NTT. Berbagai upaya dilakukan untuk membantu masyarakat, mulai dari memberikan dukungan hingga mengumpulkan donasi untuk korban banjir bandang ini.

Beragam kelompok masyarakat, pejabat, instansi pemerintah atau swasta hingga kalangan selebriti bahu-membahu mengumpulkan donasi untuk NTT. Fenomena gerakan sosial seperti ini sudah berlangsung sejak lama di Indonesia. Gerakan sosial solidaritas tidak hanya terjadi di real life saja, tetapi sudah memasuki ruang virtual seperti media sosial. Dengan hadirnya media sosial, peran teknologi tidak hanya menjadi lebih penting, tetapi juga secara fundamental telah mengubah cara orang berkomunikasi (Rosenbaum \& Bouvier, 2020).

Pada ruang virtual, konsep dari gerakan sosial digital atau opini publik mengalami perubahan konsep tradisional dalam mengumpulkan informasi opini publik dengan mediasi suatu organisasi. Hadirnya media sosial mengubah upaya pengumpulan informasi tanpa diperlukan mediasi suatu organisasi, publik dapat mengakses berbagai opini atau gerakan sosial di media sosial, salah satunya dengan penggunaan tagar-tagar tertentu (Barisione \& Ceron, 2017).

Gerakan sosial dalam media sosial memiliki peran dan fungsi yang sama pentingnya dengan penyampaian opini tradisional (offline) yang dapat dikumpulkan dengan metode survei (Tjahyana, 2020). Gerakan sosial di media sosial merupakan respon spontan masyarakat untuk menyampaikan opininya di media sosial.

Gerakan sosial di ruang publik sudah banyak dilakukan oleh berbagai pihak, di antaranya adalah penelitian Fuadi dan Tasmin (2018), memaparkan bahwa Majelis Ulama Indonesia (MUI) memanfaatkan ruang virtual secara maksimal sehingga Gerakan Nasional Pengawal Fatwa (GNPF) masih bergaung hingga saat ini. Gerakan sosial yang terjadi di Indonesia tidak selalu berkaitan dengan bencana alam, kasus-kasus diskriminasi sosial dan hukum seperti \#SaveKPK, poin untuk Prita dan \#KawalPemilu merupakan salah satu bentuk gerakan sosial masyarakat Indonesia di media sosial Twitter.

Tingginya penetrasi pengguna internet di Indonesia pada kuartal ke-2 tahun 20192020, sekitar 196,71 juta jiwa (73,7\%) dari seluruh penduduk Indonesia (APJII, 2020). Dengan distribusi penggunaan internet yang hampir menyeluruh ini, fenomena gerakan sosial di media sosial semakin berkembang secara cepat, salah satunya gerakan sosial digital \#SolidaritasUntukNTT. Gerakan sosial \#SolidaritasUntukNTT menjadi trending topic di Twitter pada saat bencana banjir bandang melanda daerah tersebut. Beragam tweet dan retweet dari berbagai pengguna Twitter untuk memberikan semangat kepedulian kepada masyarakat yang terkena dampak dari bencana tersebut. Gerakan sosial ini menunjukkan tingginya solidaritas masyarakat Indonesia mengenai bencana bandang di NTT.

Penyebaran dampak bencana banjir bandang di NTT begitu masif dilakukan di berbagai 
100 | Kajian Jurnalisme

Volume 05 Nomor 01 Tahun 2021

DOI: $10.24198 / \mathrm{jkj} . v 5 \mathrm{i} 1.33458$

platform media sosial, salah satunya Twitter. Hingga saat ini Twitter dinilai sebagai media sosial yang paling efektif dalam melakukan gerakan sosial, terutama untuk isu-isu yang menarik perhatian publik. Dengan kemampuan Twitter yang begitu besar dalam menyebarluaskan pesan secara masif dan cepat. Namun sangat disayangkan fungsi Twitter ini tidak digunakan untuk melakukan mitigasi sebelum bencana ini terjadi. Berdasarkan hasil analisis data DroneEmprit (2021), peringatan sebelum bencana sudah dilakukan oleh@InfoBMKG pada tanggal 3 April 2021. BMKG mendeteksi ada 2 (dua) bibit siklon tropis yang diberi nama Siklon Seroja. Rilis yang dikeluarkan oleh BMKG hanya diberitakan oleh Detik.com, Solopos, Radar Bogor, dan lain-lain. Hanya saja peringatan BMKG ini tidak menjadi perhatian bagi pers nasional maupun lokal. Hal ini dikarenakan beriringan dengan pernikahan selebriti Atta-Aurel yang menarik perhatian publik hingga pers.

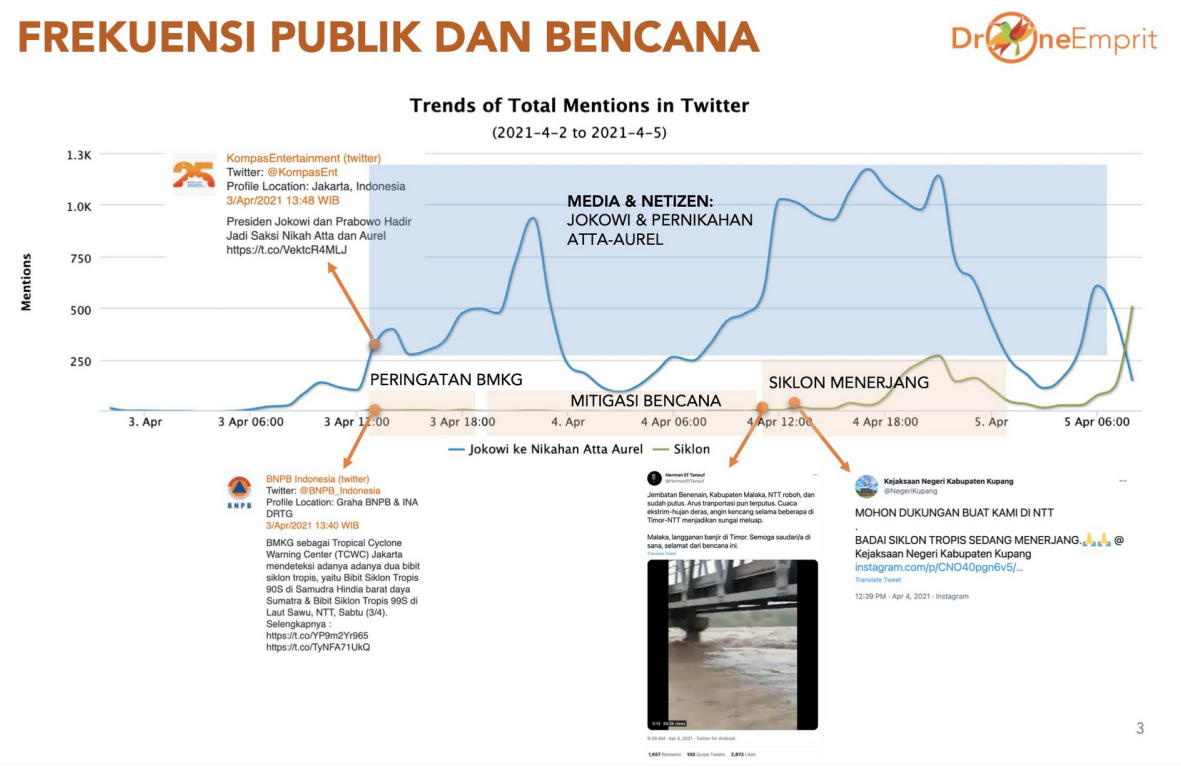

Gambar 1. Trends of Total Mentions in Twitter Sumber: (DroneEmprit, 2021)

Berdasarkan gambar 1, jumlah mentions yang dilakukan oleh pers terkait peringatan bencana alam dikalahkan oleh popularitas pernikahan selebriti. Total frekuensi berdasarkan data mentions di atas, pertama kali peringatan yang dilakukan BNPB muncul pada jam 13.40 WIB, peringatan yang diberikan oleh BNPB belum mendapatkan respon dari pers. bahkan sehari setelah peringatan dini tersebut, hampir tidak ada pers nasional atau lokal yang memberitakan mengenai Siklon Soroja, padahal di berbagai media sosial sudah mulai banyak masyarakat yang menginformasikan badai telah datang menerjang. Setelah badai terjadi pada tanggal 4 april 2021 jam 18.00, pers baru mulai memberitakan kembali fenomena tersebut, namun belum mampu menyaingi pemberitaan pernikahan artis pada hari yang sama.

Segala aktivitas kejurnalistikan di Indonesia seperti mencari data untuk dijadikan bahan pemberitaan, memperoleh data terkait pemberitaan, memiliki data, menyimpan data, mengolah data, dan menyampaikan informasi berdasarkan fakta dalam berbagai format digital dilindungi oleh UU No. 40 Tahun 1999 tentang pers. Jika pada saat peringatan pertama dari BMKG, pers aktif menginformasikan kepada masyarakat, pemerintah daerah dan masyarakat mungkin akan melakukan tindakan antisipatif untuk mengurangi dampak yang terjadi.

Dalam rilisnya DroneEmprit (2021), upaya mitigasi yang dilakukan oleh pers tidak terjadi karena pers fokus pada pernikahan Atta-Aurel, sehingga dampak yang ditimbulkan dari Siklon 
Seroja begitu masif. Pers hanya fokus pada fungsi hiburan saja, tetapi meninggalkan fungsi pers yang lainnya. Salah satunya adalah fungsi kontrol sosial sebagaimana tertulis pada pasal 33 UU no. 40 tahun 1999. Berdasarkan kejadian ini, peneliti ingin melihat peran pers dalam mendistribusikan pesan digital untuk memobilisasi gerakan sosial digital \#SolidaritasUntukNTT di Twitter pasca Siklon Seroja menerjang wilayah tersebut.

Hal inilah yang menjadi problematika dalam penelitian ini, bagaimana pers menjalankan fungsinya sebagai kontrol sosial dalam masyarakat, sebagaimana yang diterangkan dalam UU pers tersebut. Dalam konteks ini peran pers tidak terlihat semestinya, khususnya dalam aktivitasnya di media Twitter. Aktivitas pemberitaan pers nasional berfokus pada pemberitaan pernikahan artis. Berdasarkan problematika fenomena di atas, pemilihan penelitian ini berfokus pada bagaimana peran pers dalam membantu mendistribusikan gerakan sosial digital, setelah peristiwa terjadi.

Selain itu, pemilihan topik penelitian ini untuk memberikan kesadaran pada masyarakat dan pers untuk mengutamakan kepentingan nasional dibandingkan kepentingan golongan tertentu saja. Peran pers dalam negara demokrasi tidak hanya memberikan hiburan kepada masyarakat, tetapi sebagai alat kontrol kepada pemerintah jika pers menjalankan fungsi kontrol sosialnya dengan baik, dan merespons peringatan awal bencana dari BMKG. Peristiwa bencana di NTT ini dapat dijadikan evaluasi beberapa pihak di antaranya masyarakat, pers dan pemerintah untuk saling mendukung agar peristiwa serupa tidak akan memiliki dampak yang masif. Penelitian ini bertujuan untuk melihat bagaimana peran pers dalam negara demokrasi ikut dalam menyosialisasikan gerakan sosial digital di Twitter sebagai bentuk tanggung jawab pers kepada masyarakat. Pers merupakan pilar keempat atau fourth estate dalam negara demokrasi, setelah eksekutif, legislatif dan yudikatif. Menurut McNair (2018), fungsi pers dalam negara demokrasi, yaitu: fungsi pengawasan, fungsi mendidik, memberikan platform terhadap diskursus politik publik, sebagai pengawas pemerintah.

$\mathrm{Hsu}, \mathrm{Yu}, \& \mathrm{Wu}$ (2014) mengatakan bahwa media sosial memberikan peluang bagi para pengguna untuk membentuk ikatan dan membangun suatu jaringan sosial dengan berinteraksi sesamanya melalui internet. Internet telah menjadi ruang publik dalam konteks virtual. Internet memfasilitasi berbagai interaksi dan komunikasi antar penggunanya. Berdasarkan karakteristik tersebut, internet khususnya media sosial telah menjadi bagian hidup semua orang yang ada di dunia. Menurut Lim (2014), media sosial memiliki kemampuan mendorong mobilisasi dan menggalang respon dengan cepat. Penggunaan media sosial Twitter oleh masyarakat dalam peristiwa bencana banjir bandang di NTT, salah satu upaya dari masyarakat untuk melakukan mobilisasi bantuan moral bagi para korban bencana banjir di NTT. Bantuan moral bagi masyarakat dapat diberikan juga oleh pers. Salah satunya adalah upaya menyosialisasikan gerakan sosial digital. Serta dapat melihat peran pers dalam struktur jaringan masyarakat di Twitter dengan tagar \#SolidaritasUntukNTT.

Struktur jaringan masyarakat di Twitter dapat dideskripsikan dan divisualisasikan menggunakan metode analisis jaringan sosial. Segala aspek sosial yang ada dalam internet dapat dianalisis menggunakan metode analisis jaringan sosial. Menurut Bakry (2020) penelitian analisis jaringan sosial mampu mengidentifikasi perkembangan suatu jaringan dan alur informasi dalam jaringan sosial di Twitter. Berdasarkan penjabaran di atas segala fenomena sosial dalam media sosial, khususnya Twitter dapat dianalisis menggunakan perspektif analisis jaringan (network).

Network merupakan relasi antar aktor dalam interaksi di suatu jaringan. Studi jaringan menggambarkan relasi antar aktor dalam struktur sosial tertentu (Sari \& Dwiyanti, 2018). Dalam sebuah jaringan, aktor-aktor dapat terhubung karena adanya relasi di antara aktor yang 
102 | Kajian Jurnalisme

Volume 05 Nomor 01 Tahun 2021

DOI: $10.24198 /$ jkj.v5i1.33458

terlibat dalam interaksi dan komunikasi. Suatu jaringan sosial dapat terhubung oleh satu relasi atau lebih, aktor atau anggota jaringan adalah unit-unit yang dihubungkan oleh relasi yang memiliki pola (Marin \& Wellman, 2011). Pada konteks penelitian ini, jaringan yang terbentuk adalah relasi pengguna Twitter. Menurut Huberman, Romero, \& Wu (2009), hanya sekitar $13 \%$ saja dari jumlah follower atau following di Twitter yang memiliki interaksi yang kuat atau definisi teman yang sebenarnya dalam jaringan Twitter.

Terbentuknya pola jaringan komunikasi antara anggota jaringan di Twitter, karena adanya beberapa kesamaan, salah satunya adalah minat. Para aktor dalam jaringan tagar \#SolidaritasUntukNTT terhubung melalui tagar yang sama, sebagai representasi dukungan mereka terhadap masyarakat yang terkena dampak bencana alam di NTT. Ketika para anggota jaringan ingin mencari informasi maka akan merujuk pada anggota jaringan lainnya, sehingga pola jaringan akan terbentuk. Para ahli SNA (Social Network Analysis) tertarik meneliti posisi aktor dalam jaringan sosial. Bagaimana peran aktor yang satu dengan aktor yang lainnya. Posisi aktor digambarkan melalui sentralitas jaringan (Eriyanto, 2014).

Peran individu dalam sistem jaringan memiliki keterikatan yang kuat dan saling melengkapi satu sama lain. Hubungan peran individu dan sistem jaringan dijadikan sebagai ketentuan dalam mengidentifikasi setiap aktor yang memiliki peranan utama dalam jaringan sosial. Oleh karena itu, tujuan utama dari analisis jaringan sosial adalah memahami hubungan antara aktor dalam suatu jaringan serta memberikan gambaran umum jaringan yang terbentuk berdasarkan kesamaan minat tertentu. Menurut Prell (2012) ada empat level analisis jaringan, yaitu node dan nodes, komponen dan complete network.

Hubungan antara nodes dalam suatu jaringan dapat direpresentasikan dengan pendekatan teori graf. Teori graf digunakan oleh para peneliti analisis jaringan untuk mengetahui hubungan dan peran antar aktor dalam suatu jaringan, serta dapat memberikan visualisasi diagram relasi suatu jaringan sosial. Menurut Borgatti, Everett, \& Johnson (2013), diagram memiliki dua komponen, yaitu titik (node) dan garis (edge) yang menghubungkan suatu simpul. Relasi yang terbentuk dalam analisis jaringan merupakan suatu hubungan sosial yang terdiri dari simpul dan ikatan. Simpul atau ikatan yang terbentuk disebut dengan istilah edges, link, dan connections.

Node merupakan aktor yang bersifat individu atau lembaga dalam suatu jaringan, sedangkan ikatan adalah hubungan antara aktor satu dengan lainnya. Struktur sosial yang divisualisasikan dalam bentuk grafik merupakan hubungan yang kompleks dari berbagai aktor. Metode analisis jaringan sosial dapat digunakan untuk mempelajari berbagai pola jaringan komunikasi dalam berbagai fenomena interaksi dan komunikasi suatu masyarakat, suatu ide, minat dan beberapa orang dapat terhubung melalui berbagai cara, salah satunya dengan jaringan (Oktora \& Alamsyah, 2014).

Path atau jalur merupakan konsep utama dalam teori graf. Teori graf dapat diimplementasikan dalam penelitian jaringan sosial atau komunikasi dengan memberikan gambaran umum (visualisasi) para aktor (node) yang terhubung dalam relasi jaringan sosial. Peran teori graf dalam penelitian sosial sangat penting untuk menggambarkan karakteristik suatu jaringan serta mengidentifikasi aktor kunci dalam suatu jaringan sosial.

Menurut Utami (2018) dalam penelitiannya, ada 5 (lima) prinsip teori jaringan. Pertama, relasi yang terbentuk di antara aktor merupakan relasi yang resiprokal. Aktor dapat saling terhubung. Kedua, ikatan yang terjadi di antara anggota populasi dapat dikaji dalam konteks yang lebih luas. Ketiga, relasi sosial dapat membentuk berbagai pola jaringan yang terstruktur. Keempat, relasi asimetris dalam suatu jaringan dapat menimbulkan tidak meratanya distribusi sumber daya. Kelima, kompetisi atau kerja sama dapat muncul dalam suatu jaringan dikarenakan tidak meratanya distribusi sumber daya yang ada. 
Dengan berbagai prinsip teori jaringan dalam media sosial Twitter dapat dijadikan upaya memahami pola distribusi pesan yang efektif dan cepat sebagai upaya penanggulangan bencana atau mitigasi bencana di kemudian hari. Menurut Anwar, Iriani, \& Manongga (2018) upaya mitigasi melalui Twitter ini memungkinkan dilakukan, dengan mengidentifikasi pola komunikasi dan jalur distribusi pesan digital dalam jaringan Twitter menggunakan metode SNA. Oleh karena itu, hasil penelitian ini dapat dijadikan upaya mitigasi di kemudian hari untuk mengurangi dampak bencana yang terjadi.

Penelitian yang terkait dengan jaringan sosial sudah banyak dilakukan oleh penelitilainnya, khususnya dalam konteks komunikasi offline. Dengan perkembangan teknologi internet yang masif, dan penggunaan internet yang hampir menjangkau seluruh lapisan masyarakat, maka metode SNA menjadi pendekatan alternatif yang dapat diadopsi dalam konteks interaksi secara daring. Seperti halnya penelitian ini bertujuan untuk mengamati berbagai percakapan di Twitter berdasarkan topik tertentu, sehingga membentuk pola dan tipe jaringan komunikasinya. Serta peran pers sebagai aktor distribusi gerakan sosial digital di Twitter. Berikut ini penelusuran berbagai penelitian terkait jaringan sosial dan komunikasi dalam konteks offline dan online.

Penelitian Soumokil, Manongga, \& Hendry (2013) dengan menggunakan metode analisis jaringan sosial kepada komunitas pemain game Massive Multiplayer Online Role Game (MMORPG). Profil gamers yang menjadi objek analisis adalah mahasiswa yang tersebar di beberapa daerah seperti Jakarta, Jawa Barat dan Jawa Tengah. Hasil penelitian berupa visualisasi jaringan sosial antara para pemain game online serta mengukur sentralitas aktor dalam jaringan sosial, untuk mengetahui peran aktor dalam komunitas game tersebut. Hasil penelitian ini mendapatkan enam aktor yang terisolasi dan penurunan presentasi keseluruhan pengukuran degree centralitation, closeness centralization dan betweeness centrality dalam jaringan.

Penelitian lainnya terkait dengan analisis jaringan sosial adalah Sulistiawati (2018), yang mengamati peran tokoh pemuka opini dalam suatu jaringan kelompok masyarakat. Serta mengetahui peranan individu dalam suatu kelompok jaringan masyarakat. Dalam studi jaringan opinion leader merupakan salah satu key player distribusi informasi suatu jaringan.

Fatoni (2019) menganalisis Chain Network akun@infoBMKG menggunakan metode SNA. Hasil penelitian menunjukkan akun@infoBMKG memiliki beberapa sub kelompok kecil dengan diameter jaringan sebesar 34. Aktor-aktor dalam akun@infoBMKG tidak memiliki kedekatan karena arus informasi directed. Selain itu, penelitian juga dilakukan oleh Khajeheian \& Kolli (2020) pada komunitas games online Pokemon Go. Penelitian ini melakukan analisis jejaring sosial pada platform Twitter dengan menganalisis \#PokemonGo. Hasil penelitian menunjukkan bahwa game ini mempromosikan hubungan sosial pengguna dan meningkatkan percakapan di antara para pemain. Itu juga menyimpulkan bahwa perilaku sosial pengguna dipromosikan dan mereka bertindak lebih sosial, mengeksplorasi lingkungan mereka lebih memotivasi dan membuat rutinitas mereka lebih bermakna.

Berdasarkan penelitian terdahulu, peneliti berupaya mencari celah-celah kosong yang belum dieksplorasi oleh penelitian yang sejenis. Oleh karena itu peneliti berupaya menganalisis pola jaringan komunikasi dan peran sentralitas aktor dalam tagar \#SolidaritasUntukNTT sebagai upaya mitigasi bencana dalam menemukan jaringan yang efektif menjangkau semua aktor dalam Twitter sehingga dapat menyebarluaskan pesan informasi secara cepat dan mengidentifikasi Key Players dalam jaringan dengan tagar \#SolidaritasUntukNTT. Penggunaan metode SNA untuk upaya mitigasi bencana dalam sosial media merupakan kebaharuan penerapan SNA dalam analisis jaringan. Oleh karena itu yang menjadi rumusan masalah dalam penelitian ini yaitu bagaimana peran pers sebagai aktor dalam mendistribusikan gerakan sosial digital dengan 
104 | Kajian Jurnalisme

Volume 05 Nomor 01 Tahun 2021

DOI: $10.24198 / \mathrm{jkj} . v 5 \mathrm{i} 1.33458$

tagar \#SolidaritasUntukNTT di Twitter?

\section{METODE}

Penelitian ini menggunakan metode SNA (Social Network Analysis). SNA merupakan suatu cara yang digunakan untuk menganalisis relasi antara aktor dalam suatu jaringan tertentu. Studi jaringan berbeda dengan pendekatan ilmu sosial lainnya. Analisis jaringan yang menjadi fokus analisis adalah relasi antara aktor, sedangkan pada ilmu sosial lainnya fokus analisisnya adalah data atribusi. Metode analisis jaringan sosial didasari asumsi atas pentingnya hubungan antar aktor atau node. Pendekatan SNA dapat mengetahui struktur jaringan sosial, serta menjelaskan posisi utama atau pemeran kunci dalam suatu jaringan (Mbaru \& Barnes, 2017). Masalah dalam penelitian ini adalah mengetahui visualisasi jaringan yang terbentuk dengan tagar \#SolidaritasUntuk NTT dan peran pers sebagai aktor dalam jaringan sosial \#SolidaritasUntuk NTT. Untuk dapat mengetahui uraian permasalahan tersebut digunakan metode SNA.

Metode SNA dapat memberikan informasi terkait struktur dan pola jaringan serta intensitas relasi antar aktor dalam suatu jaringan. Peran sentralitas aktor dapat diketahui melalui pendekatan ini. Fokus dalam analisis ini adalah bagaimana peran pers sebagai aktor dalam jaringan dengan mendistribusikan gerakan sosial digital tagar \#SolidaritasUntuk NTT di Twitter.

Metode pengumpulan data menggunakan teknik text mining pada aplikasi Gephi. Penggunaan teknik text mining untuk mengetahui data semua akun di Twitter yang menggunakan tagar\#SolidaritasUntukNTT. Setelah data dikumpulkan, langkah selanjutnya adalah processing data.

Processing data penelitian ini dilakukan text mining (penambangan teks) dengan menggunakan keywords \#SolidaritasUntukNTT. Data yang terhimpun adalah akun-akun yang melakukan tweet, retweet, mention, reply dengan menggunakan tagar tersebut. Pada tahapan ini juga dilakukan cross check data-data yang relevan dengan masalah penelitian ini. Setelah data nodes dan edge terhimpun dalam aplikasi Gephi, langkah selanjutnya adalah analisis data jaringan utuh (complete network) dan sentralitas aktor.

Setelah tahapan processing data, selanjutnya adalah melakukan analisis data. Ada dua tahapan analisis data, yaitu peneliti melakukan analisis complete network dengan menggunakan algoritma Yifan $\mathrm{Hu}$. Alasan pemilihan algoritma Yifan Hu dikarenakan nodes yang diperoleh dari text mining penelitian ini cukup besar 12.783 Nodes. Tahapan kedua dengan melakukan analisis pada level aktor pers untuk mengetahui sentralitas aktor pers yang ada pada jaringan ini. Analisis tipe dan sentralitas aktor menggunakan aplikasi Gephi dengan bantuan teori graf untuk mengidentifikasi tipe jaringan dan sentralitas aktor pers dalam jaringan \#SolidaritasUntukNTT. Berdasarkan tahapan analisis data di atas, berikut adalah rancangan analisis data penelitian ini:

Tabel 1. Rencana Analisis

\begin{tabular}{|l|l|l|}
\hline \multicolumn{1}{|c|}{ Level Analisis } & \multicolumn{1}{|c|}{ Unit Analisis } & \multicolumn{1}{c|}{ Output Informasi } \\
\hline \multirow{2}{*}{$\begin{array}{l}\text { Tipe Relasi } \\
\text { Jaringan }\end{array}$} & Relation Type & Tipe Relasi yang terbentuk \\
\cline { 2 - 3 } & Realtion Pattern & $\begin{array}{l}\text { Bagaimana visualisasi pola komunikasi dari relasi } \\
\text { jaringan ini }\end{array}$ \\
\cline { 2 - 3 } & Network Connection & Bagaimana arah hubungan relasi dari jaringan ini \\
\hline
\end{tabular}


Volume 05 Nomor 01 Tahun 2021

DOI: $10.24198 /$ jkj.v5i1.33458

\begin{tabular}{|l|l|l|}
\hline Sentralitas Aktor & Degree Centrality & $\begin{array}{l}\text { Bagaimana Popularitas aktor dalam jaringan } \\
\text { sosial atau jumlah relasi dari dan ke aktor }\end{array}$ \\
\cline { 2 - 3 } & Closeness Centrality & Bagimana kedekatan aktor dengan aktor lainnya \\
\cline { 2 - 3 } & Betweenness Centrality & $\begin{array}{l}\text { Siapa aktor yang menjadi perantara dalam } \\
\text { jaringan }\end{array}$ \\
\cline { 2 - 3 } & Eigenvector Centrality & $\begin{array}{l}\text { Seberapa penting aktor yang memiliki relasi } \\
\text { dengan aktor lainnya. }\end{array}$ \\
\hline
\end{tabular}

Sumber: (Eriyanto, 2014)

Hasil akhir penelitian ini adalah proses analisis pada level sistem (tipe relasi jaringan) dan level aktor (sentralitas). Analisis tipe relasi jaringan memiliki tiga analisis data yaitu: tipe relasi, pola relasi dan hubungan jaringan, sedangkan level aktor memiliki empat analisis yaitu: degree centrality, closeness centrality, betweenness centrality dan eigenvector centrality (Zhang \& Luo, 2017). Ada banyak teori yang mendukung perhitungan sentralitas aktor pers dalam grafik penyebaran pesan gerakan digital \#SolidaritasUntukNTT di Twitter. Menurut Carnia et al (2021), ada rumusan 4 sentralitas aktor pada teori graf, yaitu : Pertama, Degree Centrality digunakan untuk mencari akun yang memiliki pengaruh paling besar pada penyebaran informasi di Twitter dengan melihat jumlah hubungan langsung yang dimiliki suatu aktor dengan aktor lain. Semakin tinggi nilai sentralitas derajat, semakin banyak ikatan atau relasi yang dimiliki aktor dengan aktor lain. Menurut Soumokil et al (2013) terdapat dua jenis identifikasi keberadaan aktor dalam suatu jaringan, yaitu indegree dan outdegree. Indegree adalah pesan yang mengarah ke dalam aktor (dihubungi oleh aktor lain), sedangkan outdegree adalah pesan yang mengarah ke luar aktor (menghubungi aktor lain). Untuk menghitung degree centrality value atau $\mathrm{C}_{\mathrm{D}}(\mathrm{v})$ sebagai berikut:

$$
C_{D}(v)=\frac{d(v)}{n-1}
$$

Di mana d adalah jumlah relasi (link) dan $\mathrm{n}$ adalah jumlah anggota populasi (nodes)

Analisis yang kedua, Closeness Centrality digunakan untuk mencari akun yang paling berpengaruh dengan melihat seberapa dekat aktor tersebut dengan aktor lainnya berdasarkan jarak terpendek yang diperoleh. Untuk menghitung closeness centrality value atau $\mathrm{CC}(\mathrm{v})$ sebagai berikut:

$$
\mathrm{C}_{\mathrm{C}}(\mathrm{v})=\frac{\mathrm{n}-1}{\sum \mathrm{D}_{\mathrm{ij}}}
$$

Di mana $\mathrm{D}$ adalah jalur terpendek ke aktor lain, dan $\mathrm{n}$ adalah jumlah anggota populasi (nodes).

Ketiga, Betweenness Centrality digunakan untuk mencari akun yang paling berpengaruh dalam penyebaran informasi berdasarkan sejauh mana mereka dibutuhkan sebagai penghubung dalam diseminasi informasi di jejaring sosial Twitter. Untuk menghitung betweenness centrality value atau $\mathrm{C}_{\mathrm{B}}(\mathrm{v})$ sebagai berikut:

$$
C_{B}(v)=\frac{\frac{\delta_{i j} p_{k}}{\delta_{i j}}}{n^{2}-3 n-2}
$$

Di mana $\sigma_{\mathrm{ij}} \mathrm{P}_{\mathrm{k}}$ adalah jumlah tahap terpendek dari aktor, dan $\sigma_{\mathrm{ij}}$ adalah jumlah jalur dalam jaringan, sementara nilai maksimum. Nilai Betweenness centrality normalitas adalah $0-1$, di mana mendekati 1 yang paling bagus. 
106 | Kajian Jurnalisme

Volume 05 Nomor 01 Tahun 2021

DOI: $10.24198 / \mathrm{jkj} . v 5 \mathrm{i} 1.33458$

Keempat, Eigenvector centrality digunakan untuk mencari akun yang paling berpengaruh dengan mengidentifikasi pengaruh akun tersebut di seluruh jaringan, tidak hanya pengaruhnya terhadap node yang terhubung langsung. Untuk menghitung eigenvector centrality value atau $\mathrm{C}_{\mathrm{E}}(\mathrm{v})$ sebagai berikut:

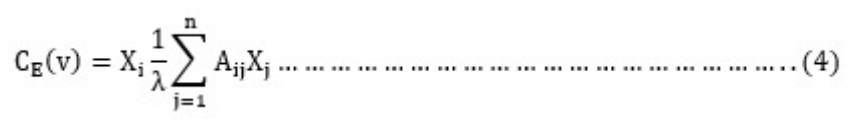

Di mana $\mathrm{A}_{\mathrm{ij}}$ adalah neighboring matrix, $n$ adalah jumlah nodes dalam graf. $\lambda$ adalah dominan nilai eigenvector.

\section{HASIL DAN PEMBAHASAN}

Dataset diperoleh dari penambangan teks (mining text) digital di Twitter menggunakan aplikasi Gephi dan plug in Twitter Streaming Importer dengan menggunakan kata kunci (keyword) \#SolidaritasUntukNTT. Berdasarkan hasil penambangan teks diperoleh jumlah nodes dan edges dalam jaringan tagar \#SolidaritasUntukNTT adalah 12.783 nodes atau aktor yang menggunakan tagar \#SolidaritasUntukNTT dan 28.451 edges atau relasi yang terbentuk di antara akun-akun yang menggunakan tagar \#SolidaritasUntukNTT. Hasil analisis data penelitian ini pada level sistem (tipe jaringan) dan level aktor (sentralitas aktor) yang dianalisis menggunakan perangkat lunak Gephi dengan algoritma Yifan Hu. Pemilihan algoritma Yifan $\mathrm{Hu}$ didasari nodes yang diperoleh cukup besar di atas 10.000 nodes dengan arah hubungan directed (Gephi, 2011). Berdasarkan analisis dengan menggunakan algoritma Yifan Hu diperoleh hasil gambaran tipe jaringan dan sentralitas pada jaringan \#SolidaritasUntukNTT.

\section{Level Sistem (Tipe Relasi)}

Jaringan merupakan tempat atau media para aktor untuk saling berkomunikasi dengan aktor lainnya. Jaringan menyediakan sebuah sistem untuk mengatur arus informasi para aktor sehingga dapat dipahami para aktor saling membangun relasi. Jaringan merupakan suatu sistem yang dinamis berdasarkan interaksi para aktornya. Jaringan sosial yang terbentuk dalam penelitian ini karena kesamaan minat pengguna dalam mendistribusikan pesan digital melalui tagar \#SolidaritasUntukNTT. Menurut Barisione \& Ceron (2017), tagar merupakan salah satu penyampaian opini masyarakat di era komunikasi digital secara bebas tanpa mediasi pihak manapun. Tagar \#SolidaritasUntukNTT merupakan upaya masyarakat digital untuk mengekspresikan opininya dalam interaksi digital. Penyampaian opini masyarakat melalui media sosial akan membentuk suatu keterhubungan atas kesamaan minat, sehingga membentuk pola jaringan yang dapat dianalisis melalui pendekatan SNA.

Pola jaringan akan berubah mengikuti pola interaksi dan komunikasi setiap aktornya. Berdasarkan analisis sistem jaringan diperoleh data media sosial Twitter memiliki karakteristik relasi dua tipe. Menurut Pryke (2012), jaringan dua tipe adalah jaringan yang memiliki aktor dengan tipe yang berbeda antara individu dan lembaga. Dalam hasil penelitian ini seperti @ aargopuro,@thaza_kun,@nurizzati_shm,@corbuzierdan lainnya sebagai individu, sedangkan yang termasukdalam lembaga adalah@vice.id,@detik.com,@metro_tv dan lainnya. 


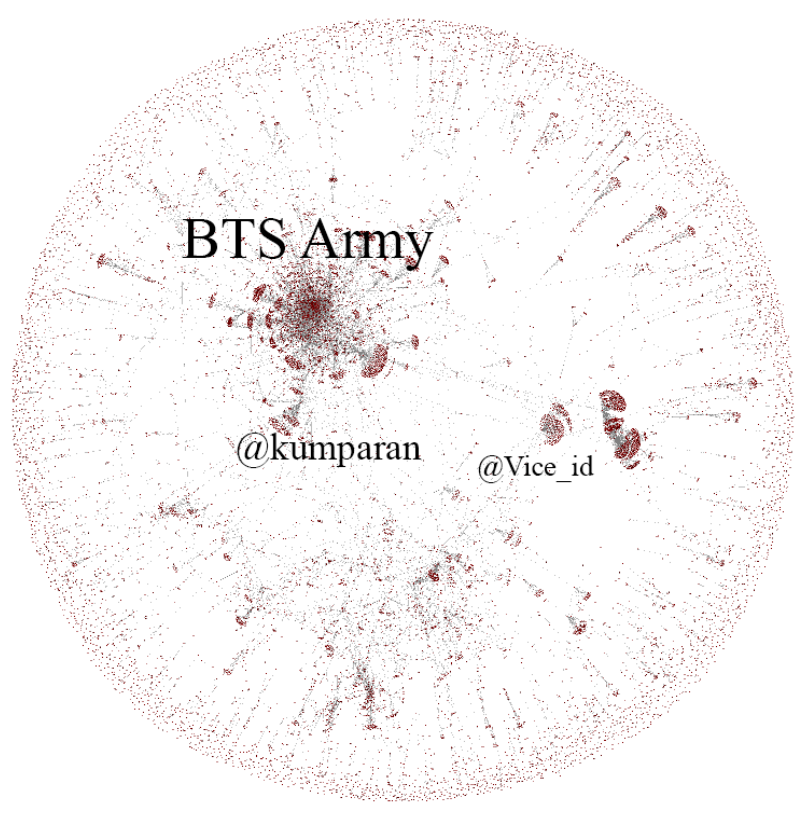

Gambar 2. Sosiogram \#SolidaritasUntukNTT dengan Aplikasi Gephi Sumber: Hasil Penelitian

Berdasarkan hasil analisis data sosiogram di atas, dengan menggunakan tagar \#SolidaritasUntukNTT yang terbentuk dari 12.783 titik atau aktor dan 28.451 garis penghubung sebagai relasi. Sosiogram di atas menunjukkan bahwa aktivitas interaksi di Twitter didominasi oleh jaringan BTS Army. Aktor sentral dalam komponen jaringan BTS Army di antaranya adalah@armyindovote,@btsvotingindo dan@bts_twt. Ketiga akun ini merupakan akun yang paling sering dihubungi oleh aktor lain ketika menggunakan tagar \#SolidaritasUntukNTT. Komponen jaringan BTS army termasuk yang paling aktif dan reaktif dalam mendistribusi gerakan sosial digital \#SolidaritasUntukNTT. Pers dalam sosiogram di atas hanya@vice_id dan@kumparan saja yang mampu mengimbangi pergerakan pesan digital dari para BTS army.

Pola jaringan sosial yang terbentuk antara aktor (nodes) dihubungkan oleh keterkaitan minat yang sama, yaitu memberikan dukungan moral kepada masyarakat yang terdampak bencana banjir di NTT. Ketika para pengguna Twitter berusaha mencari berbagai informasi yang mereka percayai dan yakini, maka mereka akan merujuk kepada pengguna Twitter lainnya. Dengan itu mereka telah membentuk atau membuka peluang terjalin relasi diantara para pengguna Twitter tersebut. Relasi dalam Twitter akan terbentuk dari aktivitas mereka melakukan quotes dari tweet aktor lain, atau memberikan like dan comment di tweet aktor lain. Hal ini selaras dengan pernyataan John \& Carrington (2011) bahwa jejaring sosial adalah himpunan pengguna yang saling berinteraksi satu dengan lainnya. Anggota jaringan yang saling terhubung dapat dianalisis pola, struktur dan karakteristik jaringannya.

Dari hasil visualisasi (gambar 2) terdapat pola komunikasi roda (radial personal network). Pola komunikasi roda adalah pola komunikasi yang terpusat dalam suatu jaringan, ada aktor yang letaknya sebagai pemberi informasi kepada kelompoknya masing-masing. Pola radial personal network memiliki kelebihan dalam distribusi pesan yang lebih efektif, karena setiap anggota populasi memiliki kesempatan untuk berinteraksi dengan orang lain (open network), sedangkan interlocking personal networks jauh lebih tertutup akan kemungkinan interaksi baru dengan pengguna yang lainnya (Rogers \& Kincaid, 1981).

Radial Personal Network memiliki tingkat keeratan hubungan antara aktor dalam suatu jaringan yang rendah, karena setiap aktor hanya terhubung pada satu aktor pusat saja. Dalam 
108 | Kajian Jurnalisme

Volume 05 Nomor 01 Tahun 2021

DOI: $10.24198 /$ jkj.v5i1.33458

jaringan \#SolidaritasUntukNTT dapat teridentifikasi aktor-aktor yang memerankan sebagai cutpoint di antaranya adalah@stberis,@taethless,@viclerens,@madeandi dan lainnya. Cutpoint merupakan peran suatu aktor dalam jaringan sosial, cutpoint berperan sebagai penghubung dan perekat dalam jaringan sosial, ketiadaan cutpoint dalam suatu jaringan akan menyebabkan jaringan terpecah pecah menjadi beberapa komponen kecil atau bahkan menjadi aktor isolate atau aktor yang tidak memiliki relasi dengan aktor lainnya (Borgatti et al., 2013). Oleh karena itu dalam studi jaringan peran dari cutpoint sangat penting untuk menyatukan suatu jaringan.

Pola komunikasi roda dalam jaringan \#SolidaritasUntukNTT adalah asimetris. Pola komunikasi yang simetris tidak melihat feedback dalam proses komunikasi yang terjadi. Pola asimetris memiliki kelebihan dan kekurangan. Kelebihannya distribusi pesan menjadi lebih cepat dan efektif, sedangkan kelemahannya pola jaringan ini tergantung dari key player, jika ada hambatan pada key player maka seluruh informasi akan mengalami kendala.

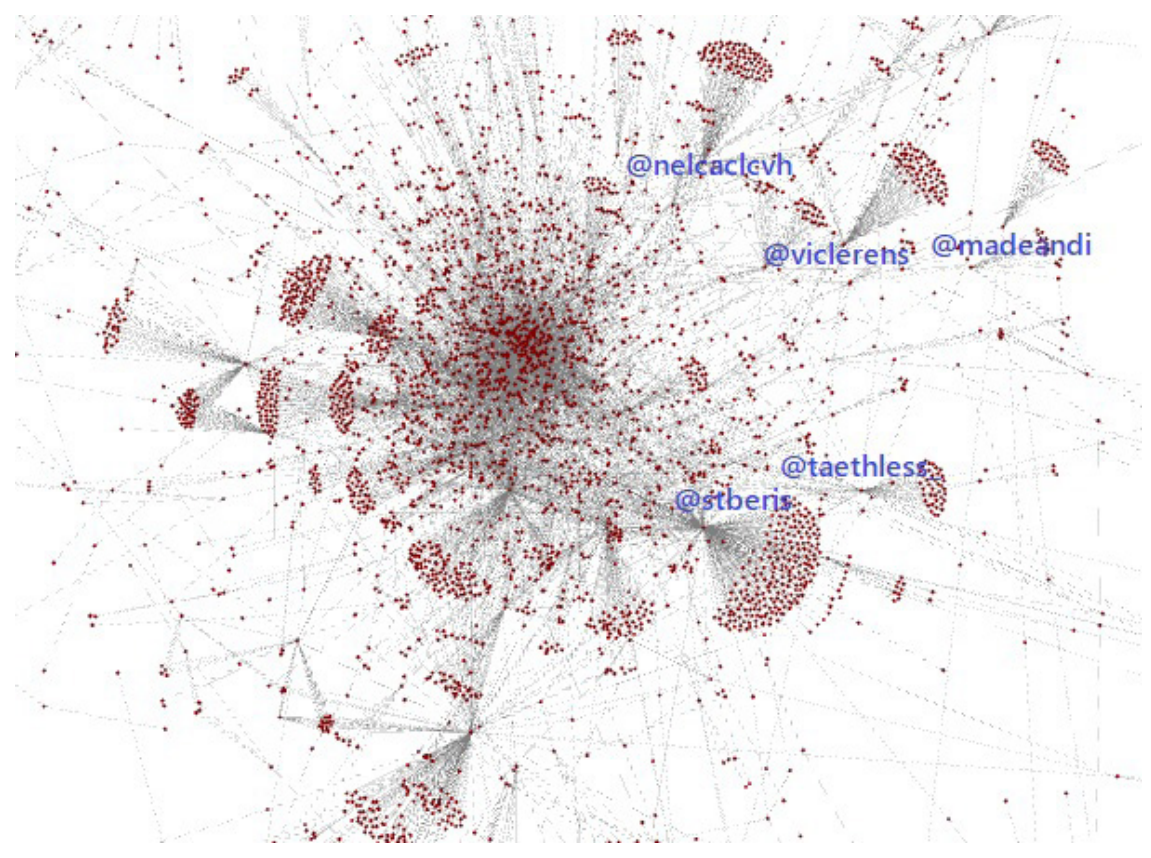

Gambar 3. Cutpoint dalam jaringan \#SolidaritasUntukNTT

Sumber: Hasil Penelitian

Analisis level sistem yang ketiga adalah arah relasi jaringan. Terdapat dua bentuk relasi jaringan, yaitu langsung dan tidak langsung. Relasi langsung adalah relasi yang memiliki arah hubungan, ada yang bertindak sebagai pengirim dan penerima pesan, sedangkan relasi tidak langsung adalah relasi yang tidak memiliki arah hubungan, peran pengirim dan peran penerima dianggap equal, keduanya memiliki peran (Bakry, 2020). Menurut Plickert, Côté, \& Wellman (2007), relasi yang menunjukkan arah (langsung) adalah relasi yang bukan resipokal, sedangkan relasi yang tidak menunjukkan arah (tidak langsung) adalah relasi yang resipokal. Hasil penelitian ini merupakan jenis relasi yang memiliki arah hubungan, ada aktor yang berperan sebagai pengirim pesan dan aktor yang menerima pesan. Aktor yang berada di pusat pola jaringan, adalah aktor yang mengirim pesan kepada aktor lainnya, hal inilah merupakan karakteristik pola komunikasi roda.

Selain dilihat dari jenis relasi, penelitian tipe jaringan dapat dikategorikan menjadi relasi simetris (dua arah) dan asimetris (satu arah). Penelitian ini merupakan tipe asimetris (satu arah). Menurut Kadushin (2012) relasi simetris adalah relasi yang bersifat dua arah, di mana dua aktor memiliki peran yang sama, jika salah satu aktor dihilangkan maka relasi tidak dapat terbentuk, 
sedangkan asimetris adalah hubungan satu arah, ada aktor yang bersifat aktif dan ada aktor yang pasif. Pada kasus ini gerakan digital \#SolidaritasUntukNTT, ada aktor yang berperan sebagai pengirim pesan dan ada aktor yang menerima pesan, oleh karena itu arah penelitian ini adalah asimetris. Hasil penelitian ini berbeda dari temuan Haythornthwaite (2005) yang menunjukkan arah relasi yang simetris pada dampak penggunaan sosial media. Hal ini bisa saja terjadi karena perbedaan unit analisis, jika dalam penelitian Haythornthwaite fokusnya adalah dampak media komunikasi dan internat pada konektivitas antar manusia, sedangkan dalam penelitian ini yang menjadi fokusnya adalah distribusi pesan gerakan digital dengan tagar \#SolidaritasUntukNTT. Distribusi gerakan digital ini dapat diidentifikasi pola penyebaran informasinya, dari yang melakukan tweet, retweet, mention, like dan comment pada jaringan ini.

\section{Level Aktor (Sentralitas)}

Analisis sentralitas aktor dapat diukur dengan 4 (empat) skala pengukuran sentralitas aktor, yaitu degree centrality, closeness centrality, betweenness centrality dan eigenvector centrality. Analisis sentralitas aktor ini digunakan untuk mengetahui peranan pers dalam mendistribusikan fenomena gerakan sosial digital \#SolidaritasUntukNTT. Berdasarkan hasil penambangan teks, sekurangnya ada 5 (lima) media arus utama yang ikut memobilisasi gerakan digital ini, di antaranya adalah@vice_id, @kumparan,@idntimes, @arusbaik_id dan @detikcom. Pemilihan kelima media ini didasari pada pencapaian terbanyak degree centrality dalam jaringan utama.

Fokus analisis data sentralitas aktor pers dianalisis pola jaringan kelima pers tersebut, yang kemudian akan dianalisis peran sentralitasnya dalam jaringan utama \#SolidaritasUntukNTT. Tujuan analisis sentralitas aktor ini untuk mengetahui seberapa jauh informasi mengenai tagar tersebut menyebar keseluruh jaringan pada media tersebut.
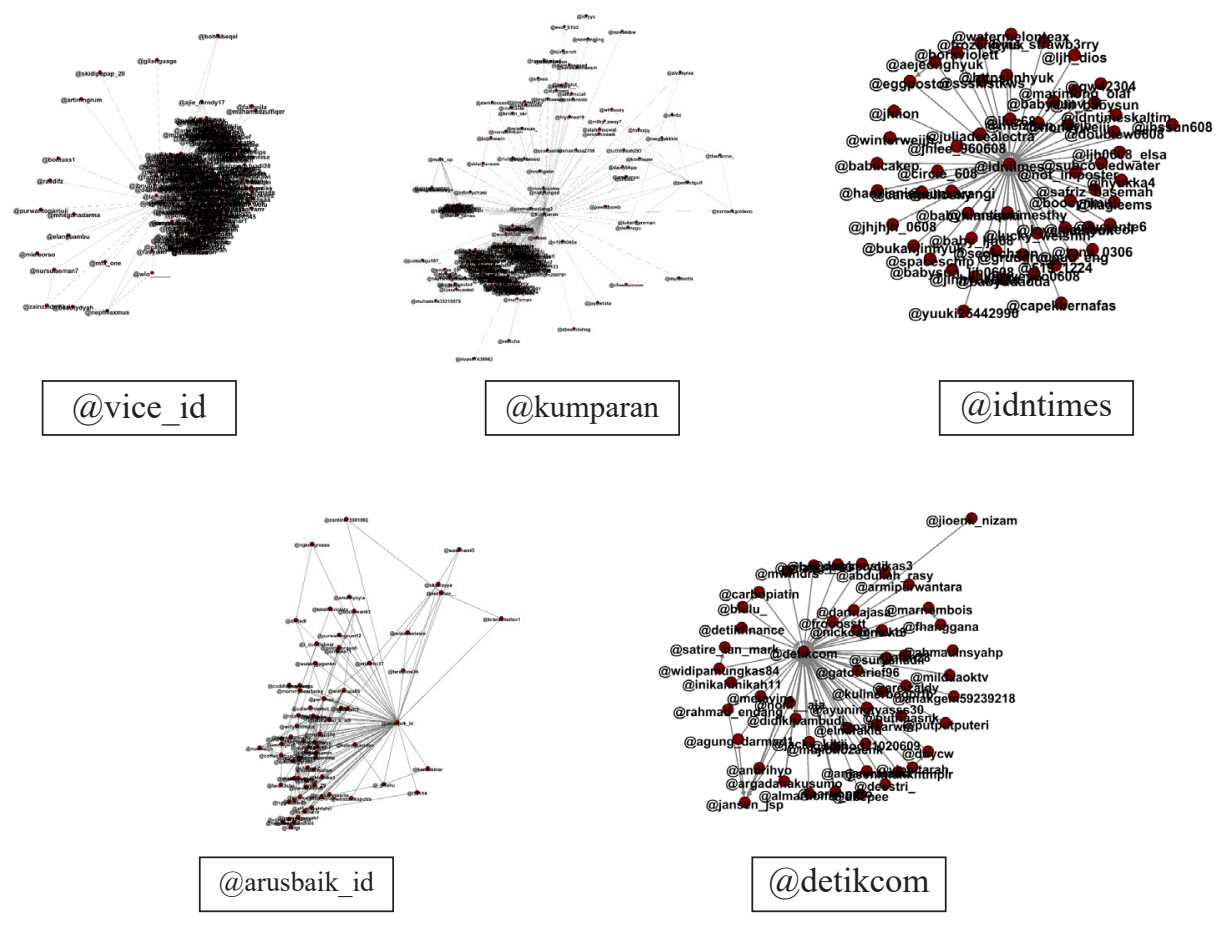

Gambar 4. Sosiogram Pers di Twitter Sumber: hasil penelitian

Berdasarkan sosiogram pers di atas, peran media dalam mendistribusikan gerakan sosial 
110 | Kajian Jurnalisme

Volume 05 Nomor 01 Tahun 2021

DOI: $10.24198 / \mathrm{jkj} . v 5 \mathrm{i} 1.33458$

digital \#SolidaritasUntukNTT kurang signifikan penyebaran informasinya, jika dibandingkan dengan jumlah follower aktif tiap media tersebut. Berikut perbandingan popularitas aktor (degree centrality) tiap jaringan pers dengan jumlah follower pers tersebut.

Tabel 2. Profil data dan dataset penelitian

\begin{tabular}{|c|c|c|c|c|c|c|c|}
\hline No & Nama Aktor & Degree & Betweenness & Closeness & Eigenvector & $\begin{array}{c}\text { Jumlah } \\
\text { Follower }\end{array}$ & $\begin{array}{c}\text { Proporsi } \\
\text { (\%) }\end{array}$ \\
\hline 1 & @vice_id & 421 & 0 & 0.0 & 0.24 & 418.458 & 0,1 \\
\hline 2 & @kumparan & 295 & 0 & 0.0 & 0.20 & 675.482 & 0,04 \\
\hline 3 & @idntimes & 109 & 55 & 1.0 & 0.06 & 408.366 & 0,02 \\
\hline 4 & @arusbaik_id & 92 & 0 & 0.0 & 0,07 & 4.806 & 1,91 \\
\hline 5 & @detikcom & 77 & 81 & 1.0 & 0,05 & 16.840 .906 & 0.00 \\
\hline
\end{tabular}

Sumber: Hasil Penelitian

Analisis Degree centrality digunakan untuk mengetahui popularitas aktor dalam jaringan sosial. Degree centrality merupakan jumlah relasi yang dimiliki dari dan ke aktor (Eriyanto, 2014). Jadi dalam konteks penelitian ini ingin mengetahui berapa jumlah relasi dari dan ke pers dengan popularitas tertinggi dalam jaringan. Media@vice_id memiliki popularitas yang tinggi di antara media lainnya sebanyak 421 relasi. Data ini dapat diartikan bahwa aktor tersebut menghubungi (outdegree) dan dihubungi (indegree) sebanyak 421 kali. Degree centrality pers kedua dimiliki oleh@kumparan dengan relasi 295.Degree centrality@idntimes,@arusbaik_ id dan@detikcom masing-masing memiliki total relasi 109, 92 dan 77. Relasi degree centrality dalam jaringan dapat diidentifikasi berdasarkan relasi masuk (indegree) dan relasi keluar (outdegree). Relasi indegree dan outdegree dalam konteks penelitian ini adalah jumlah relasi yang menghubungi kelima pers berupa mention, quote, like dan retweet pesan termasuk dalam indegree, sedangkan outdegree adalah pesan yang di mention kepada aktor lain dari pers.

Dari kelima media di atas, hanya media@idntimes dan@detikcom yang melakukan mention kepada aktor lainnya. Aktor@idntimes menyebarluaskan tagar (outdegree) \#SolidaritasUntukNTT kepada aktor@idntimeskaltim sebanyak dua kali, sedangkan aktor@ detikcom melakukan mention kepada aktor@detikfinance juga sebanyak dua kali.

Analisis kedua adalah closeness centrality. Analisis ini untuk mengetahui seberapa dekat aktor dengan semua aktor lain dalam jaringan \#SolidaritasUntukNTT. Menurut Eriyanto (2014) kedekatan suatu aktor dapat dilihat dari berapa langkah seorang aktor dapat menghubungi aktor lainnya dalam suatu jaringan. Dalam closeness centrality yang diukur adalah jalur terpendek dari satu aktor ke aktor lainnya, untuk mencapai aktor dalam jaringan ada banyak jalur yang bisa dilewati dalam perhitungan ini yang diukur adalah jalur terpendeknya.

Berdasarkan data tabelCloseness Centrality, aktor@idntimes dan@detikcom memiliki nilai 1.0, ini artinya kedua aktor ini ingin melakukan relasi dengan aktor lainnya hanya membutuhkan jarak 1 relasi saja, sedangkan ketiga aktor lainnya tidak memiliki jalur untuk melakukan relasi dengan aktor lainnya, hal ini dikarenakan relasi ketiga aktor lainnya adalah relasi indegree sehingga ketiga aktor ini bersifat pasif tanpa berusaha menghubungi aktor lainnya dalam jaringan \#SolidaritasUntukNTT.

Analisis yang ketiga adalah betweenness centrality. Analisis ini bertujuan untuk mengetahui posisi seorang aktor sebagai perantara bagi aktor lain dalam suatu jaringan (Eriyanto, 2014). Keberadaan aktor ini sangat penting untuk menyatukan aktor-aktor lainnya agar tetap terhubung dalam jaringan. Keberadaan aktor ini untuk mengetahui arus pesan yang dikirimkan dapat secara langsung atau melalui aktor perantara. Semakin tinggi nilai betweenness centrality maka semakin penting peran aktor tersebut dalam jaringan. 
Berdasarkan tabel 2 dapat diperoleh informasi nilai betweennes centrality kelima news onlinedimiliki oleh@detikcom dan@idntimes dengan nilai81dan 55.Aktor@detikcom dan @idntimes selain berperan sebagai sumber informasi dalam jaringan, juga berperan sebagai perantara atau perekat (cutpoint) dari relasi antar aktor dalam jaringan \#SolidaritasUntukNTT. Sementara itu, aktor@vide_id,@kumparandan@arusbaik_id memiliki nilai betweennes centrality 0 . Artinya ketiga news online ini tidak berperan sebagai perantara. Jika ada aktor yang ingin menghubungi aktor lainnya, tidak perlu melalui ketiganya.

Analisis yang keempat adalah eigenvector centrality, analisis ini digunakan untuk mengetahui relasi dengan aktor yang memiliki kontribusi paling sentral dalam jaringan. Dalam analisis ini tidak mengukur "berapa banyak orang yang anda kenal", tetapi "siapa orang yang anda kenal" (Eriyanto, 2014). Eigenvector centrality menunjukkan aktor terpenting dalam jaringan berdasarkan koneksi yang dimiliki aktor (Alhajj \& Rokne, 2014). Berdasarkan data di atas menunjukkan bahwa aktor @vice_id memiliki nilai eigenvector tertinggi dibandingkan dengan news online lainnya. Hal ini berarti media@vice_id memiliki hubungan dengan banyak aktor penting dalam jaringan \#SolidaritasUntukNTT.

Berdasarkan hasil analisis sentralitas aktor pers dalam menyebarluaskan pesan digital sosial di Twitter kurang signifikan dalam distribusi keseluruhan jaringan utama. Para aktor pers hanya menjadi aktor pendukung saja. Hal ini dapat terlihat dari hasil analisis sentralitas kelima media tersebut hanya memperoleh 994 popularitas dari 12.000 kemungkinan populasi yang dapat diperoleh.

Peran aktor pers dalam gerakan sosial digital tagar \#SolidaritasUntukNTT sudah menjalankan perannya dengan baik sebagaimana fungsi pers menurut McNair (2018). Pers dalam jaringan ini mampu mendistribusikan pesan gerakan sosial digital kepada pengguna Twitter. Pers dapat meningkatkan jalur distribusi pesannya jika me-mention akun-akun pemerintah atau lembaga-lembaga terkait agar pesan yang ada dapat langsung diterima oleh lembaga terkait. Pemanfaatan media sosial dapat ditingkatkan kembali, karena media sosial telah menjadi bagian dari kehidupan masyarakat. Keterbukaan informasi di media sosial salah satunya Twitter memberikan kesempatan bagi siapa saja untuk dapat mengakses dan memberikan opini terkait kondisi yang ada di masyarakat.

Twitter adalah media sosial yaang secara aktif mendistribusikan opini dan gerakan digital di masyarakat. Twitter seringkali digunakan dalam berbagai kegiatan kemanusiaan dan politik di masyarakat (Gunawibawa \& Oktiani, 2020). Kehadiran Twitter telah menggeser ruang diskusi dan parisipasi publik di seminar-seminar, perkuliahan, tempat kerja menjadi ruang diskusi ruang online. Kehadiran ruang online memberikan kesempatan bagi masyarakat untuk berinteraksi dan berdiskusi tanpa batasan ruang dan waktu.

Percakapan-percakapan yang ada di Twitter dapat diketahui pola jaringan komunikasi online melalui metode SNA. Aktor-aktor kunci dalam penyebaran pesan dan gerakan sosial digital dapat diketahui posisi dan perannya. Sebuah isu dalam Twitter dapat dilihat perkembangannya melalui pola jaringan dan aktor-aktor yang menggunakan isu tersebut. Aktor pers dalam penelitian ini bukan termasuk dalam aktor sentral, tetapi pers termasuk dalam aktor kunci dalam menyebarkan gerakan sosial digital ini menjadi lebih luas lagi.

\section{SIMPULAN}

Pers dalam penelitian jaringan ini telah memerankan fungsinya dengan baik, walau tidak menjadi pemain sentral dalam jaringan ini. Pers telah memberikan sumbangsih penyebaran gerakan sosial digital melalui jaringannya, sehingga gerakan sosial tagar \#SolidaritasUntukNTT menjadi lebih menyebar ke beberapa pengguna Twitter. Hasil penelitian yang telah dilakukan 
112 | Kajian Jurnalisme

Volume 05 Nomor 01 Tahun 2021

DOI: $10.24198 / \mathrm{jkj} . v 5 \mathrm{i} 1.33458$

pada jaringan \#SolidaritasUntukNTT, dengan melakukan penambangan teks (mining text) tweet, retweet, like, comment, quote dan mention para aktor diperoleh beberapa kesimpulan di antaranya adalah karakteristik tipe jaringan dalam penelitian ini adalah two mode. Aktor yang terlibat di dalamnya tidak hanya individu saja tapi juga lembaga dan instansi pemerintah. Selain itu pola komunikasi jaringan yang ditemukan adalah radial personal network yang memiliki ciri jaringan terbuka dan kohesivitas yang rendah jika dibandingkan dengan interlocking personal networks. Arah relasi jaringan dalam penelitian ini adalah directed dan asimetris. Arah relasi yang satu arah ini dapat terlihat jelas peran yang dimiliki tiap aktornya, ada yang sebagai menghubungi (outdegree) dan dihubungi (indegree). Pada level aktor analisis yang dilakukan adalah sentralitas aktor news online yang terhubung dalam jaringan \#SolidaritasUntukNTT. Analisis aktor pers, untuk mengetahui peranan pers dalam mendistribusi pesan solidaritas digital tersebut. Berdasarkan hasil analisis, ada lima pers yang memiliki jumlah relasi terbanyakdi antara pers lainnya, yaitu@vice_id,@kumparan,@idntimes,@arusbaik_id dan @ detikcom. Ada 4 level analisis sentralitas aktor, yaitu degree centrality, closeness centrality, betweenness centrality dan eigenvector centrality. Pada leveldegree centrality media@vice id memiliki relasi terbanyak dibandingkan dengan media lainnya sebesar 421, diikuti oleh @kumparan dengan relasi 295.Degree centrality@idntimes,@arusbaik_id dan@detikcom masing-masing memiliki total relasi 109, 92 dan 77. Hasil closeness centrality tertinggi adalah media@idntimesdan@detikcom sebesar 1.0, sedangkan ketiga media lainnya tidak memiliki nilai closeness centrality. Hal ini dikarenakan, ketiga media lainnya tidak melakukan upaya menghubungi aktor lain dalam jaringan utama. Begitu juga dengan hasil betweenness centrality hanya dimiliki oleh media@idntimes dan@detikcom, sedangkan media lainnya tidak memiliki nilai. Terakhir data eigenvector centrality menunjukkan bahwa aktor@vice id memiliki nilai eigenvector tertinggi dibandingkan dengan news online lainnya. Hal ini berarti media@vice_ id memiliki hubungan dengan banyak aktor penting dalam jaringan \#SolidaritasUntukNTT.

Dalam tatanan teoretis dan praktis, penelitian ini dapat dijadikan masukan baru bagi bidang ilmu komunikasi khususnya Social Network Analysis (SNA). Penelitian ego network dapat dilakukan untuk mengukur sentralitas aktor dalam suatu jaringan. Analisis sentralitas aktor umumnya dianalisis berdasarkan aktor yang memiliki sentralitas tertinggi saja, oleh karena itu, hasil penelitian ini dapat dijadikan sebagai wawasan baru, analisis sentralitas aktor dapat dilakukan dengan cara yang berbeda. Selain itu pada tatanan praktis, penelitian ini diharapkan memberikan sumbangsih pada penelitian jaringan sosial. Selain itu pemanfaatan media Twitter dapat digunakan untuk menyebarkan pesan-pesan kepada khalayak secara cepat dan masif.

\section{DAFTAR PUSTAKA}

Alhajj, R., \& Rokne, J. (2014). Encyclopedia of social network analysis and mining. New York: Springer Science+Business Media Publisher.

Anwar, M. T., Iriani, A., \& Manongga, D. H. (2018). Analisis pola persebaran pornografi pada media sosial dengan social network analysis. Jurnal Buana Informatika, 9(1), 43-52. https://doi.org/10.24002/jbi.v9i1.1667

APJII. (2020). Penetrasi pengguna internet 2019-2020. Buletin APJII.

Bakry, G. N. (2020). Struktur jaringan pengguna Twitter dengan tagar \#Bandunglawancovid19. Jurnal Komunikasi Global, 9(2), 209-229. https://doi.org/10.24815/jkg.v9i2.17478

Barisione, M., \& Ceron, A. (2017). A digital movement of opinion? Contesting austerity through social media. In Social Media and European Politics (pp. 77-104). London: Palgrave Macmillan. https://doi.org/10.1057/978-1-137-59890-5_4

Borgatti, S. P., Everett, M. G., \& Johnson, J. C. (2013). Analyzing social networks (J. Seaman, 
Ed.). London: SAGE Publications.

Carnia, E., Fermadona, B., Napitupulu, H., Anggriani, N., \& Supriatna, A. K. (2021). Implementation of centrality measures in graph represented information spreads with hashtag \#bersatulawancorona in Twitter. Journal of Physics: Conference Series, 1722(1). https://doi.org/10.1088/1742-6596/1722/1/012068

DroneEmprit. (2021). Siklon seroja dan Aurel - Atta. Diakses dari Drone Emprit Publications website: https://pers.droneemprit.id/siklon-seroja-dan-aurel-atta/

Eriyanto. (2014). Analisis jaringan komunikasi. Jakarta: Kencana.

Fatoni, A. (2019). Chain network akun Twitter BMKG (@infoBMKG) dalam penyebaran informasi cuaca, iklim dan gempa bumi. Mediakom: Jurnal Ilmu Komunikasi, 3(1), 1-17. https://doi.org/10.35760/mkm.2019.v3i1.1978

Fuadi, A., \& Tasmin. (2018). Gerakan sosial baru di ruang publik virtual. Hanifiya: Jurnal Studi Agama-Agama, 1(1), 48-60. https://doi.org/10.15575/hanifiya.v1i1.4261

Gephi. (2011). How to use algorithms that place the nodes inside the graphic space. Diakses dari Gephi.org website: https://gephi.org/tutorials/gephi-tutorial-layouts.pdf

Gunawibawa, E. Y., \& Oktiani, H. (2020). Politik \& bencana banjir Jakarta 2020: Analisis peta percakapan \#JakartaBanjir. Expose: Jurnal Ilmu Komunikasi, 3(1), 60. https://doi. org/10.33021/exp.v3i1.989

Haythornthwaite, C. (2005). Social networks and internet connectivity effects. Information, Communication and Society, 8(2), 125-147. https://doi.org/10.1080/13691180500146185

Hsu, C. L., Yu, C. C., \& Wu, C. C. (2014). Exploring the continuance intention of social networking websites: an empirical research. Information Systems and E-Business Management. https://doi.org/10.1007/s10257-013-0214-3

Huberman, B. A., Romero, D. M., \& Wu, F. (2009). Social networks that matter: Twitter under the microscope. SSRN Electronic Journal, 1-9. https://doi.org/10.2139/ssrn.1313405

John, S., \& Carrington, P. J. (2011). The SAGE handbook of social network analysis. New York: SAGE Publications Ltd.

Kadushin, C. (2012). Understanding social networks: Theories, concept and finding. New York: Oxford University Press.

Khajeheian, D., \& Kolli, S. (2020). Digital games get viral on social media: a social network analysis of Pokémon Go on Twitter. International Journal of Web Based Communities, 16(3), 262-278. https://doi.org/10.1504/IJWBC.2020.108632

Lim, M. (2014). Seeing spatially: People, networks and movements in digital and urban spaces. International Development Planning Review, 36(1), 51-72. https://oi.org/10.3828/ idpr.2014.4

Marin, A., \& Wellman, B. (2011). Social network analysis: An introductions. In P. Carrington \& J. Scott (Eds.), The SAGE Handbook of Social Network Analysis (pp. 11-24). London: SAGE Publications Ltd.

Mbaru, E. K., \& Barnes, M. L. (2017). Key players in conservation diffusion: Using social network analysis to identify critical injection points. Biological Conservation, 210(A), 222-232. https://doi.org/10.1016/j.biocon.2017.03.031

McNair, B. (2018). Pengantar komunikasi politik. Bandung: Nusa Media.

Oktora, R., \& Alamsyah, A. (2014). Pola interaksi dan aktor yang paling berperan pada event JGTC 2013 melalui media sosial Twitter (Studi menggunakan metode Social Network Analysis). Jurnal Manajamen Indonesia, 14(3), 201-209. https://doi.org/10.25124/jmi. v14i3.370

Plickert, G., Côté, R. R., \& Wellman, B. (2007). It's not who you know, it's how you know 
114 | Kajian Jurnalisme

Volume 05 Nomor 01 Tahun 2021

DOI: $10.24198 / \mathrm{jkj} . v 5 \mathrm{i} 1.33458$

them: Who exchanges what with whom? Social Networks, 29(3), 405-429. https://doi. org/10.1016/j.socnet.2007.01.007

Prell, C. (2012). Social network analysis: History, theory and methodology. London: SAGE. Pryke, S. (2012). Social network analysis in construction. West Sussex: Wiley Blackwell.

Rogers, E. M., \& Kincaid, D. L. (1981). Communication networks toward a new paradigm for research. New York: The Free Press.

Rosenbaum, J. E., \& Bouvier, G. (2020). Twitter, social movements and the logic of connective action: Activism in the 21 st century - an introduction. Participation: Journal of Audience \& Reception Studies, 17(1), 120-125. Diakses dari https://www.participations.org/ Volume 17/Issue 1/8.pdf

Sari, M. R., \& Dwiyanti, K. T. (2018). Teori Graf dalam analisis jejaring sosial: Hubungan aktor utama dengan pengguna internal laporan keuangan. Jurnal Akuntansi Dan Keuangan Indonesia, 15(1), 21-35. https://doi.org/10.21002/jaki.2018.02

Soumokil, O. V., Manongga, D., \& Hendry. (2013). Pengaruh sentralitas aktor dalam jaringan sosial game online massive multiplayer online role playing game menggunakan social network analysis. Seminar Nasional Teknologi Informasi Dan Komunikasi, 129-137. Diakses dari https://fti.uajy.ac.id/sentika/publikasi/makalah/2013/2013_18.pdf

Sulistiawati, A. (2018). Analisis jaringan komunikasi tingkat kelompok dalam gapoktan. Sains Komunikasi Dan Pengembangan Masyarakat [JSKPM], 2(2), 155-168. https://doi. org/10.29244/jskpm.2.2.155-168

Tjahyana, L. J. (2020). Gerakan opini digital \#Truebeauty pada Twitter untuk pemeran film adaptasi komik Webtoon. SOURCE: Jurnal Ilmu Komunikasi, 6(1), 34. https://doi. org/10.35308/source.v6i1.1759

Utami,A. B. (2018). Analisis jaringan komunikasi kelompok. Dynamic Media, Communications, and Culture, 1-35. Diakses dari http://e-journal.president.ac.id/presunivojs/index.php/ DIMCC/article/view/507

Zhang, J., \& Luo, Y. (2017). Degree centrality, betweenness centrality, and closeness centrality in social network. Proceedings of the 2017 2nd International Conference on Modelling, Simulation and Applied Mathematics (MSAM2017), 300-303. https://doi.org/10.2991/ msam-17.2017.68 